\title{
THE ESTIMATION OF THE SUBCUTANEOUS TISSUE PRESSURE BY A DIRECT METHOD ${ }^{1}$
}

\author{
By GEORGE E. BURCH AND WILLIAM A. SODEMAN \\ (From the Department of Medicine, Tulane University of Louisiana, and the Charity Hospital \\ of Louisiana, New Orleans)
}

(Received for publication May 12, 1937)

Subcutaneous tissue pressure may be defined as the pressure with which the tissue structures resist any change in their anatomical relationships. Since the pioneer work of Landerer (1) in the estimation of tissue pressure, little has been done to evaluate the importance of this factor in normal and pathological physiologic processes. Recent studies $(2,3,4)$ have shown no uniformity in normal values. The present investigation is an attempt to throw additional light upon these problems and establish standards for our technic.

\section{METHODS AND MATERIALS}

We employed a simple, direct, manometric method for the determination of tissue pressure, which is based upon the modification by Henderson, et al. (5) of Riml's technic for the determination of muscle tone. The apparatus (Figure 1) consists essentially of a U-tube water ma-

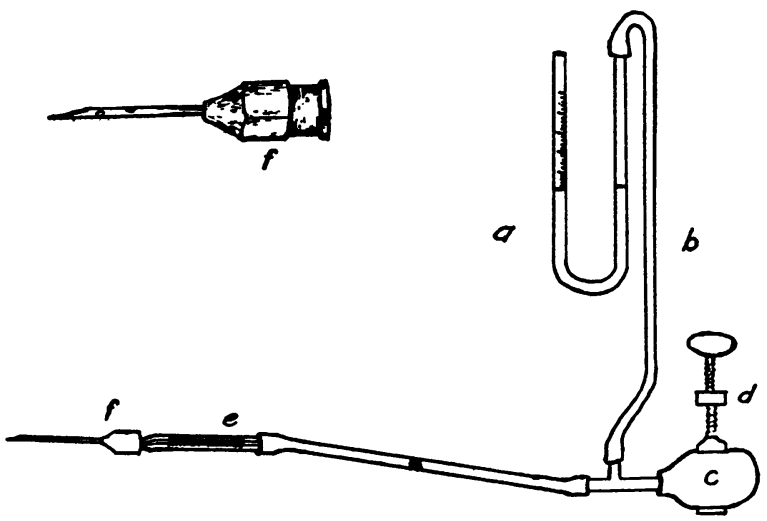

Fig. 1. Apparatus USEd in the Determination of Tissue Pressure (See Text)

nometer (a) which is connected by rubber tubing (b) to a rubber pressure bulb (c) controlled by a screw clamp (d) and also connected to a $1 \mathrm{~mm}$. bore glass adapter $(e)$ to which is fastened a 26-gauge needle $(f)$. Parallel lines were etched at millimeter intervals on the wall of the adapter so as to facilitate reading slight movements of a meniscus. The opening in the beveled end of the needle was occluded with solder and four open-

1 Presented before the American Society for Clinical Investigation at Atlantic City on May 3, 1937. ings symmetrically drilled into the lumen through the wall of its distal third. In use, sterile normal saline was drawn into the needle and about half way up the adapter, and the pressure in the system was then brought to atmospheric. The needle was then inserted into the subcutaneous tissues of the part to be studied. The pressure within the system was slowly raised by the screw clamp until the meniscus in the adapter just began to move. This pressure was taken as the subcutaneous tissue pressure. Three readings were taken which agreed within $\pm 1 \mathrm{~mm}$. for each determination. All determinations were made under aseptic conditions. At no time did we inject more than $0.5 \mathrm{cu}$. $\mathrm{mm}$. of saline and usually not more than 0.1 cu. $\mathrm{mm}$.

\section{RESULTS}

We are reporting results on normal subjects and patients with cardiac edema. A preliminary report of the results on normal subjects has already been published (6).

In 10 normal individuals the subcutaneous tissue pressure was determined at heart level in four common sites of edema formation, dorsum of the hand, volar surface of the forearm, pretibial area and dorsum of the foot. The subjects rested in the supine position for 15 minutes and the determinations were made in the order given. The results are summarized in Table I. The mean val-

TABLE I

Subcutaneous tissue pressure at heart level in normal subjects

\begin{tabular}{|c|c|c|c|c|c|c|}
\hline $\begin{array}{l}\text { Subject } \\
\text { number }\end{array}$ & Age & Sex & $\begin{array}{l}\text { Dorsum } \\
\text { of hand }\end{array}$ & $\begin{array}{c}\text { Volar } \\
\text { surface } \\
\text { of } \\
\text { forearm }\end{array}$ & $\begin{array}{c}\text { Pretibial } \\
\text { area }\end{array}$ & $\begin{array}{l}\text { Dorsum } \\
\text { of foot }\end{array}$ \\
\hline $\begin{array}{c}1 \\
2 \\
3 \\
4 \\
5 \\
6 \\
7 \\
8 \\
9 \\
10 \\
\text { Mean } \\
\text { Maximum } \\
\text { Minimum }\end{array}$ & $\begin{array}{c}\text { years } \\
23 \\
49 \\
24 \\
25 \\
25 \\
29 \\
27 \\
23 \\
26 \\
48\end{array}$ & $\begin{array}{l}\text { M. } \\
\text { M. } \\
\text { M. } \\
\text { F. } \\
\text { M. } \\
\text { M. } \\
\text { F. } \\
\text { M. } \\
\text { M. } \\
\text { M. }\end{array}$ & $\begin{array}{c}\boldsymbol{m m} \mathrm{H}_{2} \mathrm{O} \\
28 \\
12 \\
19 \\
17 \\
8 \\
15 \\
22 \\
14 \\
14 \\
30 \\
17.9 \\
30 \\
8\end{array}$ & $\begin{array}{c}\text { mm. } \mathrm{H}_{2} \mathrm{O} \\
11 \\
29 \\
26 \\
23 \\
40 \\
19 \\
18 \\
17 \\
14 \\
39 \\
23.6 \\
40 \\
11\end{array}$ & $\begin{array}{c}\text { mm. } H_{2} \mathrm{O} \\
22 \\
22 \\
23 \\
54 \\
54 \\
45 \\
40 \\
18 \\
43 \\
50 \\
37.1 \\
54 \\
18\end{array}$ & $\begin{array}{c}m m_{1} H_{2} \mathrm{O} \\
35 \\
36 \\
24 \\
15 \\
43 \\
36 \\
38 \\
18 \\
25 \\
38 \\
30.8 \\
43 \\
15\end{array}$ \\
\hline
\end{tabular}


ues at heart level varied from 17.9 to $37.1 \mathrm{~mm}$. of water, the values being slightly higher in the lower extremities. The individual determinations varied from 8 to $54 \mathrm{~mm}$. of water.

After completing the above measurements, the patient stood up and a determination was made in the dorsum of one foot while all the body weight was borne on the other foot. The pressure in the dorsum of the foot was increased in assuming the erect position in seven of the eight subjects studied, the greatest increase in any subject being 30 $\mathrm{mm}$. of water. Two of the subjects refused a fifth puncture.

When the body weight was borne equally upon both feet and the measurement of tissue pressure was repeated in the previously relaxed foot without withdrawal of the needle, the values invariably decreased. If the needle was withdrawn between these two observations, the values were increased (Table II). The latter determinations are the more accurate. Such technical difficulties are considered below.

TABLE II

Subcutaneous tissue pressure of the dorsum of the foot in normal subjects. Immediate effect of standing and bearing weight

\begin{tabular}{|c|c|c|c|c|c|}
\hline \multirow[b]{2}{*}{$\begin{array}{l}\text { Subject } \\
\text { number }\end{array}$} & \multirow[b]{2}{*}{ Age } & \multirow[b]{2}{*}{ Sex } & \multirow{2}{*}{$\begin{array}{c}\text { Standing } \\
\text { without } \\
\text { bearing weight }\end{array}$} & \multicolumn{2}{|c|}{$\begin{array}{l}\text { Standing and bearing } \\
\text { body weight }\end{array}$} \\
\hline & & & & $\begin{array}{l}\text { Needle not } \\
\text { removed }\end{array}$ & $\begin{array}{l}\text { Needle } \\
\text { removed } \\
\text { and } \\
\text { reinserted }\end{array}$ \\
\hline $\begin{array}{c}11 \\
12 \\
13 \\
14 \\
\text { Mean }\end{array}$ & $\begin{array}{c}\text { years } \\
33 \\
23 \\
26 \\
26\end{array}$ & $\begin{array}{l}\text { M. } \\
\mathbf{M} . \\
\mathbf{M} . \\
\mathbf{M} .\end{array}$ & $\begin{array}{c}\text { mm. } \mathrm{H}_{2} \mathrm{O} \\
76 \\
31 \\
66 \\
42 \\
53,7\end{array}$ & $\begin{array}{c}m m . \mathrm{H}_{2} \mathrm{O} \\
56 \\
30 \\
50 \\
12 \\
37.0\end{array}$ & $\begin{array}{c}m m . \mathrm{H}_{2} \mathrm{O} \\
100 \\
38 \\
82 \\
102 \\
80.5\end{array}$ \\
\hline
\end{tabular}

The immediate effects of elevated venous pressure were studied in the dorsum of the hand in the 10 subjects of Table $I$. With the hand at heart level, the venous pressure was increased by inflating a blood pressure cuff around the arm in steps of $135 \mathrm{~mm}$. of water $(10 \mathrm{~mm} . \mathrm{Hg})$ at two minute intervals. In no instance was the diastolic blood pressure exceeded. The results are illustrated in Table III. It can be seen that increases in venous pressure over short intervals of time had relatively slight effect on the tissue pressure readings.
TABLE III

The immediate effects of elevation in venous pressure on the determination of tissue pressure in the dorsum of the hand in normal subjects at heart level

\begin{tabular}{|c|c|c|c|c|c|c|}
\hline \multirow{2}{*}{$\begin{array}{l}\text { Subject } \\
\text { number }\end{array}$} & \multicolumn{6}{|c|}{ Pressure in cuff constricting arm ( $\mathrm{mm} . \mathrm{H}_{2} \mathrm{O}$ ) } \\
\hline & $\mathbf{0}$ & 270 & 405 & 540 & 675 & 810 \\
\hline $\begin{array}{c}1 \\
2 \\
3 \\
4 \\
5 \\
6 \\
7 \\
8 \\
9 \\
10 \\
\text { Mean }\end{array}$ & $\begin{array}{r}28 \\
12 \\
19 \\
17 \\
8 \\
15 \\
22 \\
14 \\
14 \\
30 \\
17.9\end{array}$ & $\begin{array}{c}14 \\
26 \\
16 \\
12 \\
8 \\
20 \\
19 \\
14 \\
16 \\
40 \\
18.5\end{array}$ & $\begin{array}{r}20 \\
23 \\
16 \\
12 \\
8 \\
20 \\
18 \\
14 \\
20 \\
42 \\
19.3\end{array}$ & $\begin{array}{r}22 \\
42 \\
18 \\
9 \\
10 \\
22 \\
14 \\
18 \\
16 \\
42 \\
21.3\end{array}$ & $\begin{array}{l}18 \\
45 \\
26 \\
14 \\
11 \\
33 \\
14 \\
19 \\
18 \\
46 \\
24.4\end{array}$ & $\begin{array}{c}20 \\
60 \\
28 \\
17 \\
12 \\
20 \\
* \\
16 \\
20 \\
45 \\
26.4\end{array}$ \\
\hline
\end{tabular}

* Patient's diastolic blood pressure was $60 \mathrm{~mm}$. Hg.

The effects of increased venous pressure over longer periods of time were investigated in six normal subjects standing quietly against a table inclined at $75^{\circ}$ for one hour. Measurements were made at the beginning and end of the hour. The results are presented in Table IV. The mean value for the six subjects was $53.5 \mathrm{~mm}$. of water at the beginning and 65.2 at the end of the hour. The greatest increase in any individual was 31 $\mathrm{mm}$. of water. In one instance (Subject 19) the final reading was taken after 37 minutes, just before the patient fainted. Pitting edema did not develop in any subject.

Determinations were made upon ten patients with congestive heart failure and increased venous pressure. Patients were chosen only when edema was increasing, as determined by history and inspection, and these patients were followed when possible until they became edema free. All de-

TABLE IV

The effect of standing one hour on the subcutaneous tissue pressure in the dorsum of the foot of normal subjects

\begin{tabular}{|c|c|c|c|c|}
\hline $\begin{array}{l}\text { Subject } \\
\text { number }\end{array}$ & Age & Sex & $\begin{array}{c}\text { Pressure at } \\
\text { beginning of hour }\end{array}$ & $\begin{array}{l}\text { Pressure at } \\
\text { end of hour }\end{array}$ \\
\hline $\begin{array}{c}15 \\
16 \\
17 \\
18 \\
19 \\
20 \\
\text { Mean }\end{array}$ & $\begin{array}{c}\text { years } \\
23 \\
23 \\
48 \\
46 \\
31 \\
20\end{array}$ & $\begin{array}{l}\text { M. } \\
\text { M. } \\
\text { M. } \\
\text { M. } \\
\text { M. } \\
\text { M. }\end{array}$ & $\begin{array}{c}m m . H \\
75 \\
75 \\
58 \\
94 \\
44 \\
28 \\
22 \\
53.5\end{array}$ & $\begin{array}{c}m m . \mathrm{H}_{2} \mathrm{O} \\
82 \\
60 \\
104 \\
52 \\
59^{*} \\
34 \\
65.2\end{array}$ \\
\hline
\end{tabular}

* Patient fainted after standing 37 minutes. Reading was made just before he fainted. 


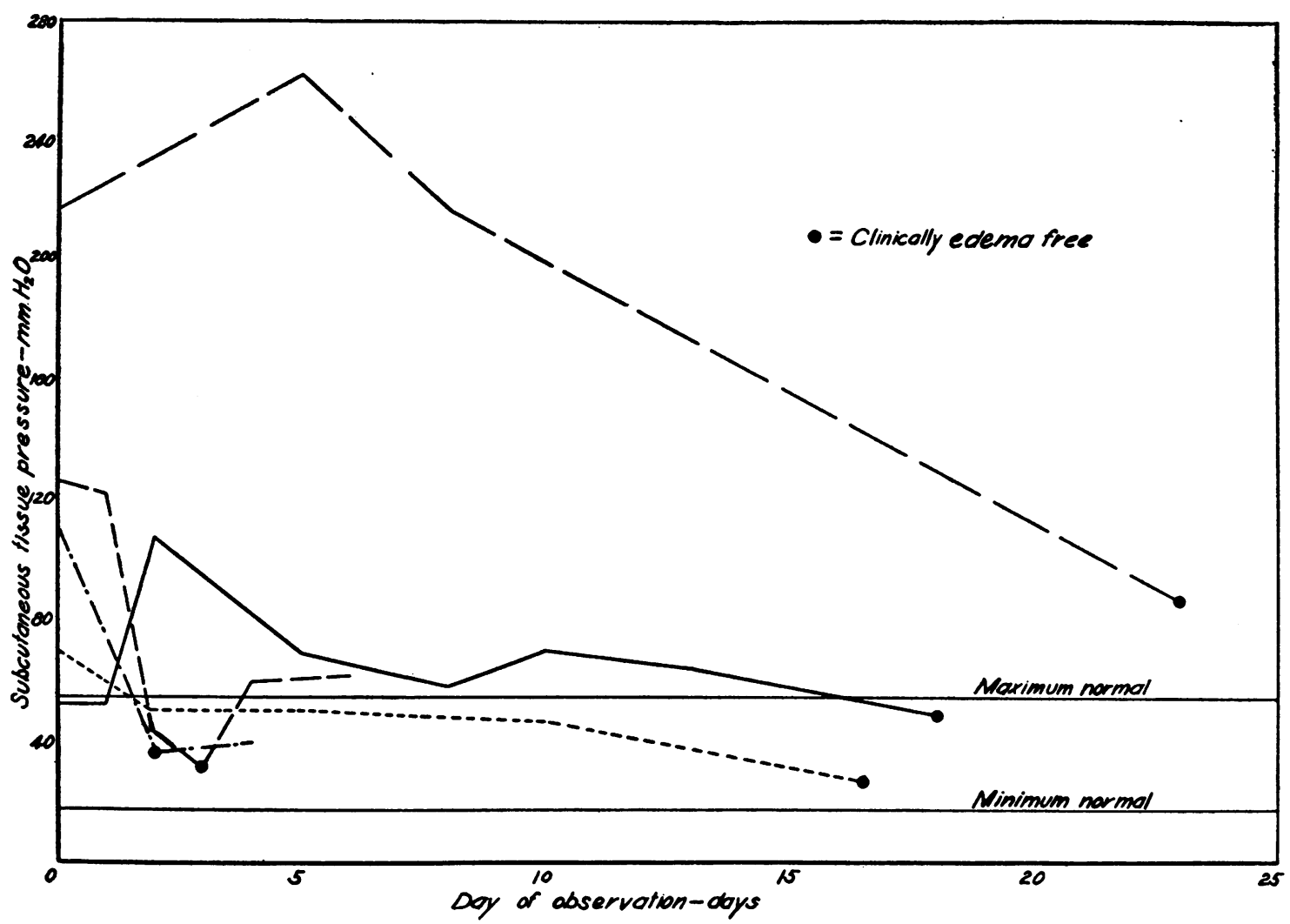

Fig. 2. Subcutaneous Tissue Pressure (Pretibial Area) in 5 Patients with Cardiac failure

terminations were made in the pretibial area in the supine position in patients confined to bed. First determinations varied from 47 to $218 \mathrm{~mm}$. of water, 9 of the 10 measurements being above 54 $\mathrm{mm}$. of water which was the highest value observed in our series of normals. Whether the value was high or low could be roughly estimated in these individuals by the appearance and firmness of the part to inspection and palpation. Figure 2 illustrates the course of the tissue pressure readings in five of the subjects followed. A great variation in the course of the pressures from patient to patient is evident. The highest value obtained in the entire group was $262 \mathrm{~mm}$. of water. In the ten patients the highest values were 188 , $126,60,242,116,156,110,262,70$, and $58 \mathrm{~mm}$. of water, respectively. In general, the readings followed the clinical course of the edema. The factors influencing these changes are analyzed in the discussion.

\section{DISCUSSION}

The importance of tissue pressure in the mechanism of fluid exchange in the body has just recently been recognized $(2,7,8)$. Indirect estimations of the tissue pressure have appeared in the American literature, but we have been unable to find records of direct determinations reported in this country. The results vary widely. Landerer (1), by a direct manometric method found that the subcutaneous tissue pressure was $550 \mathrm{~mm}$. of water in the thigh of man in the sitting position. Gildemeister and Hoffmann (3) by an indirect method with the use of an elastometer, calculated the subcutaneous tissue pressure to be $130 \mathrm{~mm}$. of water. Such indirect methods, as Landis and Gibbon (7) state, provide no information concerning the absolute tissue pressure. Meyer and Holland (4), with a direct manometric method, found a normal intracutaneous tissue pressure of 55 to $85 \mathrm{~mm}$. of water and a subcutaneous tissue pressure of 20 to $40 \mathrm{~mm}$. of water. Youmans and his associates (2), with an indirect method, calculated that the tissue pressure of the lower extremity when standing varied from 311 to 487 mm. of water. Smirk (9), in his studies on the causes of edema in congestive heart failure, found 
by a manometric method edema fluid pressures varying from 40 to $180 \mathrm{~mm}$. of water.

The great variations in the reported tissue pressure values are probably due to differences in technic. Any method which directly measures the tissue pressure may introduce errors. Our method was chosen because, as far as we could determine, it minimized error more than any technic previously described. The introduction of the needle and saline into the subcutaneous tissues tends to raise the tissue pressure. The fact that we use a small needle and inject a negligible amount of saline minimizes this effect. The tearing of tissue by the needle would tend to lower the tissue pressure. This effect is again minimized by the size of the needle employed. These two factors tend to nullify each other. Once the needle is inserted it must be maintained in position and the relationship of tissues to each other must not be changed. With movement of the part without withdrawal of the needle the change in pressure is due to at least two factors, a change in the natural relationship of tissues to each other and an interference with this change by the presence of a rigid immobile structure. Following movement of the part, withdrawal and reinsertion of the needle will eliminate this latter effect. The magnitude of such errors is illustrated in Table II. With care and experience such errors may be avoided. In five subjects repeated determinations were made in the same area with withdrawal of the needle. In three instances the determinations were made on separate days. The maximum variation for each subject was $\pm 4 \mathrm{~mm}$. of water, except in one instance in which the part could not be kept immobile and the variations were \pm 7 .

Our values for subcutaneous tissue pressure at heart level for normal individuals (Table I) agree in the main with those of Meyer and Holland (4). This pressure and the colloid osmotic pressure of the plasma are two important known antifiltering pressures which tend to neutralize the filtering pressure (hydrostatic pressure and colloid osmotic pressure of the tissue fluids). Since other factors may be important in the movement of fluid through the capillary wall, we do not feel justified in formulating an equation to quantitate these values as has been done by others $(2,4)$. This is particularly true in the light of Smirk's (9) obser- vations that capillary permeability is a variable and significant factor. Smirk's observations clearly indicate that the formula of Youmans et al. (2) is based upon erroneous assumptions. Smirk has shown that with increased venous pressure, filtering and antifiltering pressures have not reached an equilibrium even at five hours. Youmans' calculations are based upon the assumption that an equilibrium is reached at the end of one hour. Other factors such as the filtration rate, variations of the capillary bed within the part, colloid osmotic pressure of the tissue fluids, and lymph flow, which are pointed out by Smirk as important factors, are not considered in Youmans' formula. It is evident that the number of unknown factors which enter into the interchange of fluid between blood vessels and tissues is so great that a workable formula is impossible.

It is well known that an elevation in venous pressure disturbs the equilibrium between filtration and antifiltration through the capillary membrane, favoring an accumulation of interstitial fluid. The effect of this disturbance upon the tissue pressure was studied in three ways, (1) by elevation of the venous pressure for short periods of time with a blood pressure cuff, (2) by the influence of standing for one hour on determinations in the foot, and (3) by the effect of the prolonged increased venous pressure of congestive heart failure. It is evident from the data that an elevation of venous pressure for a short period of time produced no marked change in the determinations of tissue pressure. This observation is in keeping with those of Smirk, who found that an equilibrium was not established up to five hours. Since equilibrium is not established in one hour, any calculation of tissue pressure from a formula would give results that are too high (2). This explains the discrepancy between calculated values and our determinations. Prolonged elevation of venous pressure (congestive heart failure) was accompanied by a definite increase in tissue pressure. This will be discussed later.

The factors which vary tissue pressure when venous pressure is elevated are not clearly understood. There are at least three important variables, (1) the change in filtration rate, (2) distensibility of the surrounding tissues, and (3) the rate with which interstitial fluid is removed, for example, through lymphatics. Since only meas- 
urements of the first variable have been made, valid calculations of tissue pressure up to this time have been impossible, so that an accurate estimation of tissue pressure is possible only by direct measurement.

We found that the height of the arterial pressure had no direct influence upon the magnitude of the tissue pressure. It is interesting to point out that determinations of intravascular pressure by collapse technic are in error by the value of the tissue pressure. This error is small for high (arterial) pressures, but may become large in low (capillary, venous) pressures. Since the tissue pressure is unaffected by hypertension, comparison of capillary pressure by collapse technic in normal and hypertensive individuals is valid (10).

In increasing cardiac edema, we invariably found elevated subcutaneous tissue pressure. These findings are in accord with those of Smirk (9). These values depend upon the three variables previously mentioned, (1) increase in filtration rate, (2) distensibility of the surrounding tissues, and (3) the rate at which interstitial fluid is removed. In cardiac edema, interstitial fluid is accumulating more rapidly than it is being removed. As this fluid accumulates, the tissues are displaced and the fibrous network is stretched, the tissue tension increases and this in turn alters the filtration and removal rates. The interplay of these three factors influences the level to which tissue pressure may rise. It is possible that prolonged elevated tissue tension may overstretch these fibers so that with reduction of venous pressure and removal of edema they will not immediately return to their original state (7). Such a situation could explain the low tissue pressure found in receding edema and the post-edematous period (Figure 2). Such changes could explain the variable results of Meyer and Holland. In one instance the administration of salyrgan produced profuse diuresis resulting in a marked decrease of the edema and the tissue pressure as well. Diuretics, therefore, may influence tissue pressure.

In three of the patients with cardiac edema, the venous and tissue pressures were observed simultaneously. It was noted that the return of the tissue pressure to normal lagged behind the venous pressure. At no time did the tissue pressure reading exceed the venous pressure determination.
Should tissue pressure exceed venous or capillary pressure, collapse of these vessels would ensue.

Values for non-cardiac edema will be reported later.

\section{SUMMARY AND CONCLUSIONS}

Using a direct manometric method for the determination of tissue pressure, we found in 10 normal individuals mean values at heart level varying from 17.9 to $37.1 \mathrm{~mm}$. of water in the subcutaneous tissue of the dorsum of the hand and foot, volar surface of the forearm and the pretibial area. The tissue pressure in the dorsum of the foot was increased in the erect position and further increased by weight bearing. Normal tissue pressure was less than the accepted values for capillary and venular pressure.

The full effect of increased venous pressure on tissue pressure was not immediate; up to one hour the effect was slight. In congestive heart failure with prolonged high venous pressure the tissue pressure was greatly elevated.

In 10 patients with increasing cardiac edema, the tissue pressure was definitely increased. In receding cardiac edema the values were lowered, at times even below normal, to return finally to a normal level.

Tissue pressure is an important factor in the control of movement of fluid between blood vessels and tissue spaces. Factors other than venous pressure are important in the regulation of tissue pressure.

\section{BIBLIOGRAPHY}

1. Landerer, A., Die Gewebesspannung in ihren Einfluss auf die örtliche Blut- und Lymphbewegung. Leipzig, 1884.

2. Youmans, J. B., Wells, H. S., Donley, D., and Miller, D. G., The effect of posture (standing) on the serum protein concentration and colloid osmotic pressure of blood from the foot in relation to the formation of edema. J. Clin. Invest., 1934, $13,447$.

3. Gildemeister, M., and Hoffmann, L., Uber Elastizität und Innendruck der Gewebe. Pflugers Arch. f. d. ges. Physiol., 1922, 195, 153.

4. Meyer, F., and Holland, G., Die Messung des Druckes in Geweben. I. Arch. f. Exper. Path. u. Pharmakol., 1932, 168, 580.

5. Henderson, Y., Oughterson, A. W., Greenberg, L. A., and Searle, C. P., Muscle tonus, intramuscular 
pressure and the venopressor mechanism. Am. J. Physiol., 1935-36, 114, 261.

6. Burch, G. E., and Sodeman, W. A., Studies in tissue pressure. Proc. Soc. Exper. Biol. and Med., 1937, 36, 256.

7. Landis, E. M., and Gibbon, J. H., Jr., The effects of temperature and of tissue pressure on the movement of fluid through the human capillary wall. J. Clin. Invest., 1933, 12, 105.

8. Weech, A. A., Goettsch, E., and Reeves, E. B., The flow and composition of lymph in relation to the formation of edema. J. Exper. Med., 1934, 60, 63.

9. Smirk, F. H., Observations on the causes of oedema in congestive heart failure. Clin. Sc., 1935-36, $2,317$.

10. Ellis, L. B., and Weiss, S., The measurement of capillary pressure under natural conditions and after arteriolar dilatation; in normal subjects and in patients with arterial hypertension and with arteriosclerosis. J. Clin. Invest., 1929-30, 8, 47. 